\title{
Enteropathy-Associated T-Cell Lymphoma
}

National Cancer Institute

\section{Source}

National Cancer Institute. Enteropathy-Associated T-Cell Lymphoma. NCI Thesaurus.

Code C4737.

A mature T-cell and NK-cell non-Hodgkin lymphoma of intraepithelial T-lymphocytes. It usually arises from the small intestine, most commonly the jejunum or ileum. Other less frequent primary anatomic sites include the duodenum, stomach, colon, or outside the gastrointestinal tract. It is characterized by the presence of pleomorphic medium-sized to large T-lymphocytes with vesicular nuclei, prominent nucleoli, and moderate to abundant pale cytoplasm. It is associated with celiac disease. 